\title{
TINGKAT KEJADIAN AEROMONASIS PADA IKAN KOI (Cyprinus carpio carpio) YANG TERINFEKSI Myxobolus koi PADA DERAJAT INFEKSI YANG BERBEDA
}

\author{
AEROMONASIS INCIDENCE RATE IN KOI (Cyprinus carpio carpio) THAT \\ INFECTED Myxobolus koi AT DIFFERENT DEGREES OF INFECTION
}

\author{
Riris Ulfiana, Gunanti Mahasri dan Hari Suprapto \\ Fakultas Perikanan dan Kelautan Universitas Airlangga \\ Kampus C Mulyorejo - Surabaya, 60115 Telp. 031-5911451
}

\begin{abstract}
Myxobolus infection in koi fish allows followed by opportunistic microorganisms infection. Aeromonas hydrophila bacteria classified as opportunistic because it can cause illness in certain condition such as when environmental conditions change, stress and the condition of the host that has been infected by the parasite. This study purpose to determine the incidence rate Aeromonasis in koi (Cyprinus carpio carpio) infected Myxobolus koi at different degrees of infection.

The results showed that of 120 samples taken, infected with $M$. koi in a mild degree of infection is $68.3 \%$. Furthermore the medium infection is $22.5 \%, 1.7 \%$ severe infection and uninfected fish $7.5 \%$. Each level of infection of $M$. koi taken samples for examination bacteria with skin samples and water. The results of bacterial examination showed that 17 positive samples of fish infected with A. hydrophila (85\%) from 20 fish sample. 17 positive samples of fish infected with A. hydrophila consist of 3 sample normal fish, 7 sample $M$. koi mild infection, 6 sample $M$. koi medium infection and 1 sample severe infection. The results showed that the fish infected or not infected with M. koi, positive with $A$. hydrophila infection that needs to be done by using a bacterial colony calculation method of determining the Angka Lempeng Total (ALT) or Total Plate Count (TPC). The calculation results from the number of bacterial colony in various levels of infection of $M$. koi are sample 1 (normal koi fish) of $1.15 \times 10^{8}$ $\mathrm{CFU} / \mathrm{ml}$, sample 2 (koi fish with a mild infection of $M$. koi) as much as $1.3 \times 10^{8} \mathrm{CFU} / \mathrm{ml}$. While the sample 3 (koi fish with a medium infection of $M$. koi) $2.02 \times 10^{8} \mathrm{CFU} / \mathrm{ml}$ and sample 4 (with the severe infection of M. koi) $2.60 \times 10^{8} \mathrm{CFU} / \mathrm{ml}$.
\end{abstract}

Keywords : Aeromonas hydrophila, Myxobolus koi, pathogen in koi fish

\section{Pendahuluan}

Ikan hias merupakan salah satu komoditi perikanan yang memiliki peluang untuk dikembangkan. Ikan koi (Cyprinus carpio carpio) adalah ikan hias air tawar yang digemari masyarakat saat ini. Serangan hama dan penyakit merupakan salah satu kendala bagi pembudidaya ikan koi di Desa Kemloko, Kecamatan Nglegok Kabupaten Blitar terutama parasit Myxobolus koi. M. koi menginfeksi insang ikan dan dalam lembar insang $M$. koi membentuk kista (Supriyadi, 2004). Pecahnya kista pada kulit dan insang menyebabkan pendarahan intens dan menyebabkan infeksi sekunder bakteri oportunistik (Paperna and Overstreet, 1981).

Salah satu mikroorganisme yang digolongkan dalam bakteri oportunistik adalah bakteri Aeromonas hydrophila karena mampu menyebabkan penyakit pada kondisi tertentu diantaranya perubahan kondisi lingkungan, stress dan kondisi inang yang telah terinfeksi oleh parasit (Swann and White, 1989). Bakteri
A. hydrophila dapat menginfeksi melalui permukaan tubuh yang luka atau insang kemudian masuk ke dalam pembuluh darah dan organ dalam lainnya (Kabata, 1985).

Berdasarkan latar belakang maka rumusan masalah penelitian ini adalah Bagaimanakah derajat infeksi $M$. koi pada ikan koi (Cyprinus carpio carpio) di Desa Kemloko, Kecamatan Nglegok Kabupaten Blitar serta Berapakah tingkat kejadian Aeromonasis pada ikan koi yang terinfeksi $M$. koi pada derajat infeksi yang berbeda. Tujuan dari penelitian ini adalah untuk mengetahui derajat infeksi $M$. koi pada ikan koi (Cyprinus carpio carpio) di Desa Kemloko, Kecamatan Nglegok Kabupaten Blitar dan untuk mengetahui tingkat kejadian Aeromonasis pada ikan koi yang terinfeksi $M$. koi pada derajat infeksi yang berbeda. Manfaat dari penelitian ini diantaranya adalah memberikan informasi ilmiah dan pengetahuan tentang derajat infeksi $M$. koi pada ikan koi (Cyprinus carpio carpio) di Desa Kemloko, Kecamatan Nglegok Kabupaten Blitar serta 
kejadian infeksi $A$. hydrophila pada ikan koi yang terinfeksi $M$. koi pada derajat infeksi yang berbeda sehingga dapat dijadikan acuan oleh pembudidaya ikan untuk melakukan pencegahan penyakit agar tidak terjadi kerugian dalam budidaya ikan koi.

\section{Metodologi}

Sampel Ikan yang Digunakan

Ikan koi berumur 1-2 bulan diperoleh dari kolam budidaya di Desa Kemloko, Kecamatan Nglegok, Kabupaten Blitar dengan ukuran 3-5 cm. Sesuai dengan ketetapan Badan Standar Nasional Indonesia (2000), bahwa pengambilan sampel yang dilakukan untuk pemeriksaan kesehatan ikan adalah $1 \%$ dari populasi. Total populasi tiap petak adalah 3000 ekor sehingga diambil 30 ekor ikan koi sebagai sampel di tiap petak. Dari 4 petak didapatkan 120 ekor ikan yang kemudian dikelompokkan berdasarkan derajat infeksi $M$. koi. Dari setiap derajat infeksi $M$. koi kemudian diambil sampel kembali untuk dilakukan pemeriksaan bakteri di Balai Karantina Ikan Kelas I Juanda.

\section{Pemeriksaan Dan Penentuan Derajat Infeksi} Myxobolus koi

Pemeriksaan $M$. koi dilakukan secara mikroskopis dengan cara mengambil nodul dari insang ikan kemudian digerus sehingga diperoleh cairan yang berisi spora. Spora diamati di bawah mikroskop dengan perbesaran 1000x dan diidentifikasi dengan melihat morfologi sporanya. Setelah dilakukan pemeriksaan secara mikroskopis ikan yang terinfeksi $M$. koi dikelompokkan berdasarkan derajat infeksinya kemudian disampling kembali untuk dilakukan isolasi bakteri dengan menggunakan nodul dan luka pada insang ikan sebagai sumber isolasi.

Isolasi, Identifikasi dan Penentuan Prevalensi bakteri $A$. hydrophila

Isolasi dan identifikasi bakteri dilakukan dengan mengambil isolat dari insang ikan. Adapun isolasi dan identifikasi bakteri adalah sebagai berikut :

\section{Isolasi Bakteri}

Isolasi bakteri menggunakan media Triptic Soy Agar (TSA) yang bertujuan untuk mendapatkan bakteri yang menyerang sampel yang diduga terinfeksi bakteri. Sumber isolasi pada ikan adalah nodul dan luka pada insangnya.

\section{Pemurnian Bakteri}

Pemurnian ini merupakan kelanjutan dari isolasi bakteri yang bertujuan untuk mengidentifikasi mikroorganisme penyebab penyakit dengan menggunakan media TSA. Karena yang dicari dalam penelitian ini adalah penyakit yang disebabkan oleh bakteri $A$. hydrophila maka pemurnian bakteri dilakukan dengan cara mengambil koloni bakteri yang memiliki ciri morfologi koloni $A$. hydrophila 3. Identifikasi bakteri

Identifikasi bakteri meliputi pemeriksaan morfologi, pewarnaan gram, dan uji biokimia antara lain : uji $\mathrm{O} / \mathrm{F}$, uji oksidase, uji katalase, uji motilitas, produksi indol, uji TSIA, LIA dan uji Cimmon's citrate. Karakteristik biokimia bakteri $A$. hydrophila dapat dilihat pada tabel 1 . sebagai berikut :

Tabel 1. Karakteristik Biokimia Bakteri Acromonas hydrophila (Austin and Austin, 2007).

\begin{tabular}{|c|c|c|}
\hline No & Parameter & $\begin{array}{c}\text { Austin and } \\
\text { Austin } \\
(2007)\end{array}$ \\
\hline 1 & Gram & Negatif \\
\hline 2 & bentuk bakteri & Batang \\
\hline 3 & Oksidase & + \\
\hline 4 & Katalase & + \\
\hline 5 & $\mathrm{O} / \mathrm{F}$ & Fermentatif \\
\hline 6 & Motil & Motil \\
\hline 7 & arginine dihydrolase & + \\
\hline 8 & Indole & + \\
\hline 9 & lysine decarboxylase & $\mathrm{V}$ \\
\hline 10 & $\mathrm{H}_{2} \mathrm{~S}$ & - \\
\hline 11 & ornitine decarboxylase & - \\
\hline 12 & Voges Proskauer & $\mathrm{v}$ \\
\hline 13 & Methyl red & - \\
\hline 14 & Gelatin & + \\
\hline 15 & Urea & - \\
\hline 16 & Glukosa & + \\
\hline 17 & Lactose & + \\
\hline 18 & Arabinose & $\mathrm{V}$ \\
\hline 19 & Mannitol & + \\
\hline 20 & Sukrosa & + \\
\hline 21 & Inositol & - \\
\hline
\end{tabular}

4. Penentuan Prevalensi Bakteri A. hydrophila

Setelah diketahui derajat infeksinya maka dilakukan pemeriksaan bakteri dengan nodul dan luka pada insang sebagai sumber isolasi di Laboratorium Bakteriologi Balai Karantina Ikan Juanda. Kejadian atau prevalensi 
Aeromonasis pada ikan koi dinyatakan dalam bentuk persen.

Prevalensi Aeromonasis $=$

Jumlah ikan yang terinfeksi A.hydrophila x 100\% Jumlah total sampel

Penghitungan Angka Lempeng Total (ALT) atau Total Plate Count (TPC)

Penentuan Angka Lempeng Total (ALT) atau Total Plate Count (TPC) ini bertujuan untuk mengetahui jumlah koloni bakteri pada sampel Ikan koi yang telah diidentifikasi. Perhitungan ALT/TPC dilakukan terhadap sampel ikan dari tiap tingkatan infeksi $M$. koi sehingga tiap tingkatan infeksi $M$. koi diambil satu sampel biakan bakteri untuk ditumbuhkan pada media Plate Count Agar (PCA). Bakteri yang telah diisolasi, diencerkan terlebih dahulu sebelum ditumbuhkan pada media PCA. Proses penghitungan ALT/TPC dilakukan berdasarkan BSN (2006) yaitu dengan menggunakan rumus sebagai berikut:

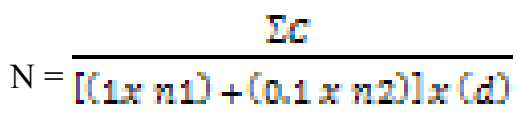

Keterangan:

$\mathrm{N}$ : Jumlah koloni produk, dinyatakan dalam koloni per $\mathrm{ml}$

$\Sigma C$ : Jumlah koloni pada semua cawan yang dihitung

n1 : Jumlah cawan pada pengenceran pertama yang dihitung

n2 : Jumlah cawan pada pengenceran kedua yang dihitung

d : adalah pengenceran pertama yang dihitung

\section{Hasil dan Pembahasan}

Benih ikan koi diambil dari kolam petani di Desa Kemloko, Kecamatan Nglegok, Kabupaten Blitar, Jawa Timur. Benih ikan yang diambil berumur 1-2 bulan dengan ukuran 3-5 cm sebanyak 120 ekor dari 4 kolam budidaya. Identifikasi $M$. koi dilakukan secara mikroskopis dengan cara mengambil nodul dari insang ikan kemudian digerus sehingga diperoleh cairan yang berisi spora. Spora diamati di bawah mikroskop dengan perbesaran 1000x dan diidentifikasi dengan melihat morfologi sporanya. Hasil pengamatan secara makroskopis menunjukkan bahwa morfologi spora yang diamati sesuai dengan karakteristik spora M. koi.

Setelah mengidentifikasi spora $M$. koi selanjutnya dilakukan pengelompokkan derajat infeksi $M$. koi yang dibagi menjadi 4 kategori yaitu ikan yang sehat apabila tidak terdapat nodul, infeksi ringan apabila terdapat 1-4 nodul, infeksi sedang bila terdapat 5-8 nodul dan derajat infeksi berat bila terdapat lebih dari 8 nodul pada insang ikan (Titis dkk, 2009). Dari pengamatan yang dilakukan didapatkan komposisi ikan sebagaimana dapat dilihat pada Tabel 2.

Tabel 2. Tingkat Infeksi Myxobolus koi Pada Benih Ikan Koi.

\begin{tabular}{|c|l|c|}
\hline no & \multicolumn{1}{|c|}{ Derajat infeksi } & $\begin{array}{c}\text { Jumlah ikan } \\
\text { koi }\end{array}$ \\
\hline 1 & Normal $(0$ nodul) & $9(7.5 \%)$ \\
2 & Ringan $(1-4$ nodul) & $82(68,3 \%)$ \\
3 & Sedang (4-8 nodul) & $27(22,5 \%)$ \\
4 & Berat $(>8$ nodul) & $2(1,7 \%)$ \\
\hline
\end{tabular}

Berdasarkan tabel di atas sebagian kecil benih ikan koi termasuk dalam derajat infeksi berat, diikuti derajat infeksi sedang dan tertinggi adalah derajat infeksi ringan. Keragaman derajat infeksi dikarenakan pada saat pengambilan sampel benih ikan koi yang berumur 1-2 bulan, proses pembelahan dan perkembangan spora $M$. koi pada setiap inang berbeda akan tetapi sebagian besar benih ikan koi terinfeksi dalam derajat infeksi ringan dan sedang. Menurut Komarudin (1991) dalam Helmiati dkk (2001) semakin kecil ukuran ikan maka semakin rentan terhadap infeksi $M$. koi karena pada ukuran benih semua organ tubuh belum berfungsi secara sempurna sehingga dapat dikatakan bahwa benih merupakan fase kritis dan mudah terserang penyakit.

Pada tahapan isolasi dan identifikasi bakteri, dilakukan sampling kembali dari total sampel ikan di setiap tingkatan infeksi $M$. koi . Benih ikan koi sehat sebanyak 3 ekor, tingkat infeksi ringan 10 ekor, tingkat infeksi sedang 6 ekor dan tingkat infeksi berat sebanyak 1 ekor. Dari semua tingkatan infeksi didapat 20 ekor sampel ikan untuk isolasi dan identifikasi bakteri $A$. hydrophila. Bagian tubuh ikan yang digunakan sebagai bahan isolasi adalah insang yang terdapat nodul maupun luka akibat infeksi $M$. koi. Karakteristik biokimia bakteri Aeromonas berdasarkan hasil isolasi dan identifikasi dapat dilihat pada Tabel 3.

Berdasarkan hasil uji biokimia di atas maka bakteri yang diamati memiliki karakteristik biokimia sesuai dengan karakteristik biokimia bakteri A. hydrophila pada tabel 1. Hasil pemeriksaan bakteri $A$. hydrophila pada benih ikan koi dari berbagai tingkatan infeksi $M$. koi dapat dilihat pada Tabel 4. 
Tabel 3. Hasil Uji Biokimia Bakteri Yang Diisolasi Dari Benih Ikan Koi Yang Terinfeksi Myxobolus

\begin{tabular}{|c|c|c|c|}
\hline no & Parameter & $\begin{array}{c}\text { Austin and Austin } \\
\text { (2007) }\end{array}$ & $\begin{array}{c}\text { Hasil } \\
\text { Pengamatan }\end{array}$ \\
\hline 1 & Gram & Negatif & Negatif \\
\hline 2 & bentuk bakteri & Batang & Batang \\
\hline 3 & Oksidase & + & + \\
\hline 4 & Katalase & + & + \\
\hline 5 & $\mathrm{O} / \mathrm{F}$ & Fermentatif & Fermentatif \\
\hline 6 & Motil & Motil & Motil \\
\hline 7 & arginine dihydrolase & + & + \\
\hline 8 & Indole & + & + \\
\hline 9 & lysine decarboxylase & $\mathrm{v}$ & + \\
\hline 10 & $\mathrm{H}_{2} \mathrm{~S}$ & - & - \\
\hline 11 & ornitine decarboxylase & - & $\mathrm{v}$ \\
\hline 12 & Voges Proskauer & $\mathrm{v}$ & + \\
\hline 13 & Methyl red & - & $\mathrm{v}$ \\
\hline 14 & Gelatin & + & + \\
\hline 15 & Urea & - & - \\
\hline 16 & Glukosa & + & + \\
\hline 17 & Lactose & + & - \\
\hline 18 & Arabinose & $\mathrm{v}$ & - \\
\hline 19 & Mannitol & + & + \\
\hline 20 & Sukrosa & + & + \\
\hline 21 & Inositol & - & - \\
\hline
\end{tabular}

Tabel 4. Hasil Pemeriksaan Bakteri Aeromonas hydrophila Pada Benih Ikan Koi Dari Berbagai Tingkatan Infeksi Myxobolus koi.

\begin{tabular}{|c|l|c|c|c|}
\hline No & Derajat infeksi & Jumlah sampel & Hasil pemeriksaan & Jumlah bakteri \\
\hline 1 & Tidak ada nodul & 3 & +3 & $1,15 \times 10^{8}$ \\
2 & Ringan & 10 & +7 & $1,3 \times 10^{8}$ \\
3 & Sedang & 6 & +6 & $2,02 \times 10^{8}$ \\
4 & Berat & 1 & +1 & $2,60 \times 10^{8}$ \\
\hline
\end{tabular}

Berdasarkan pengamatan terhadap 20 sampel ikan didapatkan hasil bahwa 17 sampel positif terinfeksi bakteri $A$. hydrophila $(85 \%)$. Menurut Rukyani (1990), infeksi Myxobolus dapat menyebabkan perubahan histopatologi pada daerah sekitar nodul dalam insang seperti odema, hyperthropy, inflamasi, kongesti dan hyperplasia. Dapat dikatakan bahwa ikan yang terinfeksi M. koi lebih mudah terinfeksi bakteri A. hydrophila dibandingkan ikan sehat, sebab luka akibat pecahnya nodul dapat menjadi jalan masuk bagi bakteri A. hydrophila ke dalam tubuh ikan. Selain itu, infeksi $M$. koi juga mempengaruhi daya tahan tubuh ikan sehingga ikan yang sakit lebih mudah terinfeksi $A$. hydrophila yang merupakan bakteri oportunistik. Sedangkan ikan sehat memiliki daya tahan tubuh yang baik lebih sulit terinfeksi meskipun bakteri A. hydrophila terdapat di peraiaran. Hasil tersebut didapat dengan menghitung menggunakan rumus prevalensi sebagai berikut : 
Prevalensi Aeromonasis $=$

Jumlah ikan yang terinfeksi A. hydrophila X 100\% Jumlah total sampel

$$
=\underline{17} \times 100 \%=85 \%
$$

20

Akan tetapi dari hasil isolasi dan identifikasi bakteri didapatkan hasil bahwa ikan yang sehat atau tidak terinfeksi $M$. koi juga positif terinfeksi $A$. hydrophila, hal tersebut dikarenakan pada air di kolam budidaya telah teridentifikasi positif A. hydrophila. Berdasarkan hasil pengamatan tersebut maka perlu dilakukan perhitungan koloni bakteri dengan menggunakan metode penentuan Angka Lempeng Total (ALT) atau Total Plate Count (TPC). Perhitungan ALT atau TPC ini bertujuan untuk mengetahui apakah tingkat infeksi $M$. koi berpengaruh terhadap jumlah bakteri pada insang ikan koi.

Bakteri yang telah diisolasi, diencerkan terlebih dahulu sebelum ditumbuhkan pada media Plate Count Agar (PCA). Pengenceran dilakukan dengan cara mengambil sampel bakteri yang akan diperiksa dengan ose kemudian dimasukkan ke dalam $10 \mathrm{ml}$ laruran Butterfield's Phosphate Buffered (BFP) kemudian homogenkan menggunakan vortex. Homogenat ini merupakan larutan dengan tingkat pengenceran $10^{-1}$. Larutan pengenceran $10^{-1}$ diambil $1 \mathrm{ml}$ menggunakan pipet volumetrik steril kemudian dimasukkan ke dalam $9 \mathrm{ml}$ larutan BFP dan dihomogenkan untuk mendapatkan pengenceran $10^{-2}$. Proses diulangi dengan mengambil $1 \mathrm{ml}$ larutan pengenceran $10^{-2}$ dan dimasukkan ke dalam 9 $\mathrm{ml}$ larutan BFP untuk mendapatkan pengenceran $10^{-3}$. Proses terus diulangi sampai mendapat larutan hingga pengenceran $10^{-7}$. Jumlah total mikroba terbanyak terdapat pada sampel dengan pengenceran pertama yakni $10^{-1}$ dan semakin menurun pada pengenceran berikutnya. Tingkat pengenceran yang ditanam pada media PCA adalah pengenceran $10^{-4} 4,10^{-5}$, $10^{-6}$ dan $10^{-7}$ akan tetapi perhitungan ALT/TPC menggunakan pengenceran $10^{-5}$ dan $10^{-6}$. Hal tersebut dikarenakan pada pengenceran $10^{-5}$ dan pengenceran $10^{-6}$ koloni yang tumbuh berkisar antara 25-250 yang merupakan syarat dalam perhitungan ALT/TPC.

Hasil perhitungan jumlah koloni bakteri diberbagai tingkat infeksi $M$. koi berdasarkan rumus di atas adalah sebagai berikut, sampel 1 (ikan koi normal) sebanyak $1,15 \times 10^{8} \mathrm{CFU} / \mathrm{ml}$, sampel 2 (ikan koi dengan infeksi M. koi ringan) sebanyak $1,3 \times 10^{8}$ $\mathrm{CFU} / \mathrm{ml}$. Sedangkan sampel 3 (ikan koi dengan infeksi $M$. koi sedang) $2,02 \times 10^{8} \mathrm{CFU} / \mathrm{ml}$ dan sampel 4 (ikan koi dengan infeksi $M$. koi berat) $2,60 \times 10^{8} \mathrm{CFU} / \mathrm{ml}$. Berdasarkan perhitungan jumlah koloni bakteri diberbagai tingkatan infeksi $M$. koi, maka hubungan infeksi M. koi terhadap tingkat kejadian infeksi bakteri $A$. hydrophila dapat digambarkan dalam grafik korelasi seperti pada Gambar 1.

Dari pengambilan data kualitas air di

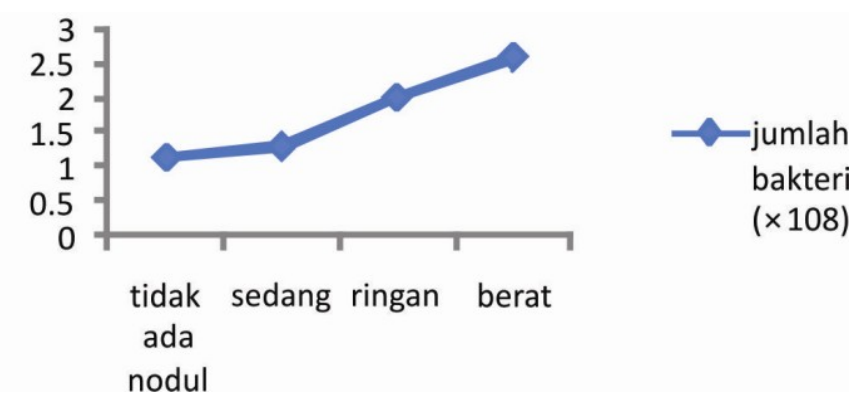

Gambar 1. Grafik Korelasi Tingkat Infeksi Myxobolus koi Terhadap Jumlah Bakteri Aeromonas hydrophila Pada Ikan Koi

Tabel 5. Data Kualitas Air Di Kolam Budidaya Ikan Koi Desa Kemloko, Kecamatan Nglegok, Kabupaten Blitar.

\begin{tabular}{|l|c|}
\hline \multicolumn{1}{|c|}{ Parameter } & Hasil \\
\hline Suhu & $28^{\circ} \mathrm{C}$ \\
$\mathrm{pH}$ & 6 \\
Oksigen terlarut & $9 \mathrm{mg} / 1$ \\
Amonia & $0 \mathrm{mg} / 1$ \\
\hline
\end{tabular}


kolam budidaya ikan koi Desa Kemloko, Kecamatan Nglegok, Kabupaten Blitar, Jawa Timur didapatkan hasil pada Tabel 5.

Ditinjau berdasarkan data kualitas air di kolam budidaya ikan koi Desa Kemloko, Kecamatan Nglegok, Kabupaten Blitar, Jawa Timur, menunjukkan bahwa kondisi air kolam dalam keadaan normal namun beberapa kondisi kualitas air pada kolam ikan koi tersebut tidak sesuai atau tidak berada dalam kisaran normal bagi kelangsungan hidup ikan koi. Kondisi kualitas air yang normal pada kolam ikan koi yang diamati adalah suhu, ammonia dan oksigen terlarut. Sedangkan $\mathrm{pH}$ perairan yang rendah berada diluar batas toleransi kondisi optimum untuk benih ikan koi. Nilai suhu pada kolam budidaya adalah $28^{\circ} \mathrm{C}$, nilai tersebut masih dalam kondisi optimum bagi kehidupan ikan. Menurut Laili (2007), kondisi suhu optimum dalam budidaya ikan koi berkisar antara $25-30^{\circ} \mathrm{C}$. nilai oksigen terlarut di perairan kolam budidaya adalah $9 \mathrm{mg} / \mathrm{l}$ sedangkan nilai amonia diperairan adalah $0 \mathrm{mg} / \mathrm{l}$. Nilai oksigen terlarut tersebut dapat dikatakan jenuh karena nilai oksigen terlarut minimum yang bisa ditoleransi oleh ikan adalah 5,0 mg/l (Afrianto dan Liviawaty, 1992). Sedangkan $\mathrm{pH}$ di kolam budidaya ikan koi adalah 6 yang menunjukkan bahwa air pada kolam budidaya bersifat agak asam dan nilai tersebut tidak memenuhi kriteria optimum $\mathrm{pH}$ perairan untuk budidaya ikan. Menurut Laili (2007) kisaran optimum $\mathrm{pH}$ perairan untuk budidaya ikan berkisar antara 78. Helmiati dkk. (2001) menyatakan bahwa parameter kualitas air yang berpengaruh terhadap prevalensi $M$. koi adalah $\mathrm{pH}$.

\section{Kesimpulan}

Adanya kondisi yang tidak optimal untuk benih ikan koi menyebabkan kondisi benih ikan koi tidak optimal sehingga mudah terinfestasi $M$. koi ataupun terinfeksi bakteri $A$. hydrophila.

\section{Daftar Pustaka}

Afrianto E. dan E. Liviawati. 1992. Pengendalian Hama dan Penyakit. Kanisius. Yogyakarta.

Austin, B. and D.A. Austin. 1999. Bacterial Fish Pathogens: Disease Of Farmed And Wild Fish, Third Edition. Praxis Publishing Ltd. Chicester, UK.

Austin, B. and D.A. Austin. 2007. Bacterial Fish Pathogens: Disease Of Farmed And Wild Fish, Fourth Edition. Praxis Publishing Ltd. Chicester, UK.

Badan Standar Nasional Indonesia. 2000. Induk Ikan Gurami (Osphronemus gouramy,
Lac) Kelas Induk Pokok (Parent Stock). Badan Standar Nasional.

Badan Standar Nasional. 2006. Cara Uji Mikrobiologi- Bagian 3: Penentuan Angka Lempeng Total (ALT) pada Produk Perikanan. Badan Standar Nasional. Jakarta.

Helmiati, S., Triyanto., dan H.N. Kamiso. 2001. Prevalensi dan derajat Infeksi Myxobolus sp. Pada Insang Benih Karper (Cyprinus carpio L.) Di Kabupaten Sleman Jawa Tengah. Jurnal Perikanan. Jurusan Perikanan Fakultas Pertnian UGM. Yogyakarta.

Kabata, Z. 1985. Parasites and Disease of Fish Cultured in The Tropics. Philadelphia: International Development Research Council.

Laili, S. 2007. Pengaruh Pemberian Ekstrak Temulawak (Curcuma xanthorrhiza Roxb) Terhadap Prevalensi dan Kelulushidupan Ikan Mas (Cyprinus carpio) yang Diinfeksi Bakteri Aeromonas hydrophyla. Fakultas Sains dan Teknologi, Jurusan Biologi, Universitas Negeri Malang. Malang.

Paperna, I. \& Overstreet, R.M., 1981. Parasites and diseases of Mullets (Mugilidae). In: Oren, O.H. (ed.) Aquaculture of Grey Mullets. IBP 26, Cambridge University Press, U.K.

Rukyani, A. 1990. Histopathological Changes in The Gill Of Common Carp (Cyprinus carpio L.) Infected with the Myxosporean Parasite Myxobolus Koi Kudo,1920. Research Institute for Freshwater Fisheries. Bogor, Indonesia.

Supriyadi, H. 2004. Membuat Ikan Hias Tampil Sehat Dan Prima. Agro Media Pustaka. Jakarta.

Swann, L, and M. R. White., 1989. Diagnosis and Treatment of "Aeromonas hydrophila" Infection of Fish. http:// www.extension.purdue.edu/extmedia/A S/AS-461.pdf/8/4/2011.2hal.

Titis C. D., W. S. D. Nugroho, D. Daenuri, Sumayani dan H. Nurul. 2009. Laporan Uji coba Identifikasi dan Penentuan Derajat Kerusakan Akibat Infeksi Myxobolus sp. Pada Ikan Mas (Cyprinus carpio). Balai Karantina Ikan Kelas II Tanjung Emas Semarang. 